\title{
POTENTIAL OF CORN HUSK LEAVES FOR THE CO-REMOVAL OF PHENOL AND CYANIDE FROM WASTE WATER USING SIMULTANEOUS ADSORPTION AND BIODEGRADATION
}

\author{
Priya Sengupta $^{1}$, Chandrajit Balomajumder ${ }^{2}$ \\ ${ }^{I}$ Research Scholar, Department of Chemical Engineering, IIT Roorkee, Roorkee, Uttarakhand, India \\ ${ }^{2}$ Associate Professor, Department of Chemical Engineering, IIT Roorkee, Roorkee, Uttarakhand, India
}

\begin{abstract}
Application of biosorbents has gained a great importance in the present scenario of waste water purification. The present work concentrates on the potential of biosorbent, Corn husk leaves, for the co-removal of phenol and cyanide from coke waste water by simultaneous adsorption and biodegradation (SAB). The microbe used in the present study is the bacteria of Serratia Sp. The entire $S A B$ process was carried out at $30^{\circ} \mathrm{C}$ and for $60 \mathrm{~h}$. Theoptimum process parameters i.e. $\mathrm{pH}$, initial concentration of both phenol and cyanide, adsorbent dose of corn husk leaves were analysed and their impact on the entire process were also studied. At the range of initial concentration of phenol between $100-1000 \mathrm{mg} / \mathrm{L}$ and cyanide between 10-100 $\mathrm{mg} / \mathrm{L}$, the optimum pH was obtained between 6.57 and an optimum adsorbent dose of $6 \mathrm{~g} / \mathrm{L}$. Multicomponent adsorption isotherms applied were Non-modified Langmuir, Modified Langmuir, Extended Langmuir and Extended Freundlich. Out of the four isotherms applied non-modified Langmuir isotherm proved to be the best fit for phenol and modified Langmuir isotherm was found to be best fit for cyanide. Phenol showed a removal percentage of $75 \%$ by SAB process and cyanide showed a removal percentage of $83 \%$. The data was also non-linearly modelled for kinetic studies. Kinetic studies revealed that for both phenol and cyanide simultaneous adsorption and biodegradation took place by physisorption as well as by chemisorption. Surface diffusion is dominating for the simultaneous adsorption and biodegradation of phenol whereas in case of cyanide intraparticle diffusion is the dominating factor.
\end{abstract}

Keywords: biosorbents, corn husk leaves, simultaneous adsorption and biodegradation, optimum.

\section{INTRODUCTION}

Phenolics are organic compounds discharged in waste water from different industries like insecticides, pesticides, textile, dye, pulp and paper, iron and steel industries [1]. Phenols in the environment are highly toxic to humans in their short term or long term exposure. Exposure to phenol causes gastrointestinal disorders, vomiting, depression and even death [2]. Cyanides are a group of chemicals that have the $-\mathrm{CN}$ bond. These inorganic compounds are discharged from industries like mining, electroplating, iron and steel industries [3]. Cyanide exposure also causes heart problems, breathing disorders and even death (Cyanide Uncertainties). Phenols and Cyanides are also listed in CERCLA priority list of hazardous substances[4]. There are a couple of methods to reduce the phenol and cyanide concentration in industrial discharge to its MCL (Maximum Contaminant Level) which is $0.5 \mathrm{mg} / \mathrm{L}$ and $0.2 \mathrm{mg} / \mathrm{L}$ for phenol and cyanide respectively $[5,6]$. Simultaneous adsorption and biodegradation of toxic pollutants is one of the developingtechniques for purification of waste water [7]. This process has an advantage of simultaneous bed regeneration along with its being cost effective [8]. The use of biosorbents has become much prominent in the present times. Biosorbents or simply the agricultural waste are easily available, the process is cost effective and they have proved to be quite efficient in the removal of toxic compounds from waste water [9].

The authors in this study have considered corn husk leaves as an adsorbent and Serratia Sp. Bacteria as the microbe for simultaneous adsorption and biodegradation of phenol and cyanide. The operating parameters i.e. $\mathrm{pH}$, adsorbent dose, initial concentration were also optimized and the data obtained was non linearly modeled for different adsorption isotherms and kinetic models.

\section{MATERIALS AND METHODS}

\subsection{Chemicals and Adsorbents}

All the chemicals used in this study were of analytical grade and obtained from Himedia Laboratories Pvt. Ltd. Mumbai India. $0.189 \mathrm{~g}$ of $\mathrm{NaCN}$ was dissolved in $1 \mathrm{~L}$ of millipore water (Q-H2O, Millipore Corp. with resistivity of $18.2 \mathrm{MX}-\mathrm{cm}$ ) to prepare a stock solution of cyanide concentration of $100 \mathrm{mg} / \mathrm{L}$. The $\mathrm{pH}$ of the cyanide stock solution was adjusted to $10 \mathrm{using}$ $1 \mathrm{~N} \mathrm{NaOH}$. The phenol stock solution, with the concentration of $1000 \mathrm{mg} / \mathrm{L}$, was prepared by adding $1 \mathrm{~g}$ of pure phenol 
crystals to $1 \mathrm{~L}$ of millipore water. Finally a binary mixture stock solution of $1000 \mathrm{mg} / \mathrm{L}$ phenol and $100 \mathrm{mg} / \mathrm{L}$ cyanide was prepared by the individual stock solutions.

Waste corn caps were collected from local shops. The fibers were removed from the corn caps. The Corn husk leaves obtained after removal of the fiber the caps were washed twice with tap water to get rid of the dirt particles. The husk leaves were then washed twice with Millipore water. After that the husk leaves were dried at $500 \mathrm{C}$ for $24 \mathrm{~h}$. When the leaves were completely dried they were crushed to a size of $1.7 \mathrm{~mm}$. Thepercentage of ash and moisture in the adsorbent is 5.702 and 12.95 respectively as obtained by proximate analysis of corn husk leaves. The functional groups were estimated using Fourier Transform Infrared Spectroscopy (FTIR, Nicolet 6700, USA). Fig 1 and 2 depict the FTIR spectrum of Corn Husk leaves before and after adsorption of phenol and cyanide. From Fig. 1 it can be seen that there is a strong vibrational peak at $3437.24 \mathrm{~cm}-1$ which showed the presence of $-\mathrm{OH}$ or $\mathrm{NH}$ functional groups. The peak at $2357.19 \mathrm{~cm}-1$ corresponds to $-\mathrm{CH}$ stretching and the next peak at $1638.88 \mathrm{~cm}-1$ between $1650-1550 \mathrm{~cm}-1$ showing the presence of secondary amines. From Fig. 2 it can be seen that after adsorption there is a shifting of peak from $3437.24 \mathrm{~cm}-1$ to $3430.89 \mathrm{~cm}-1$ in the primary aliphatic alcohol $(\mathrm{OH})$ region which shows the adsorption of phenol on Corn husk leaves. Further the next prominent shifting of peak at $2357 \mathrm{~cm}-1$ to $2358.63 \mathrm{~cm}-1$ shows the $-\mathrm{CH}$ stretching due to carbonate structures, carboxylic groups and conjugate hydrocarbons again indicating the adsorption of phenol. There is also a visible shifting of peak in amine region i.e. from $1638.88 \mathrm{~cm}-1$ to $1642.92 \mathrm{~cm}-1$ which indicates the adsorption of $-\mathrm{CN}$, as a secondary amine group.

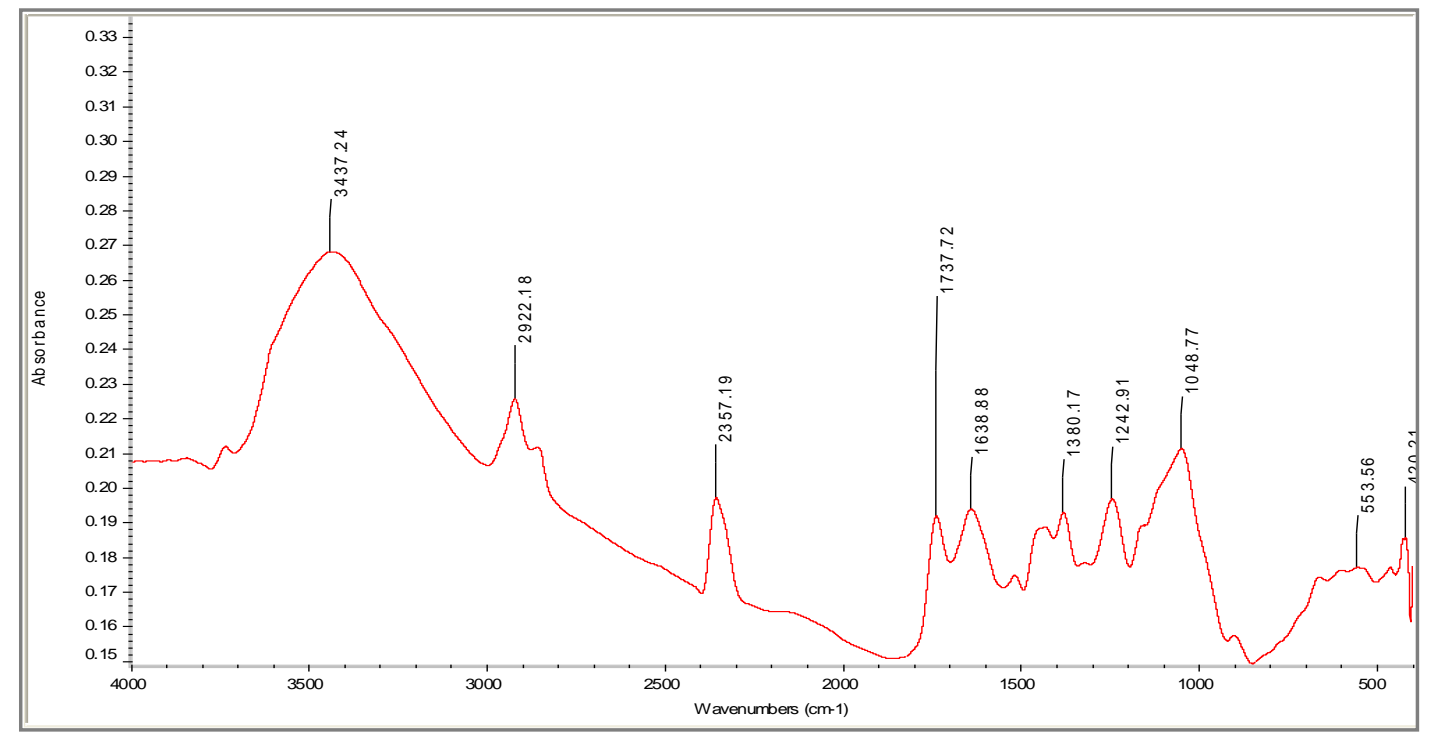

Fig-1: FTIR Spectra of Corn Husk Leaves before adsorption

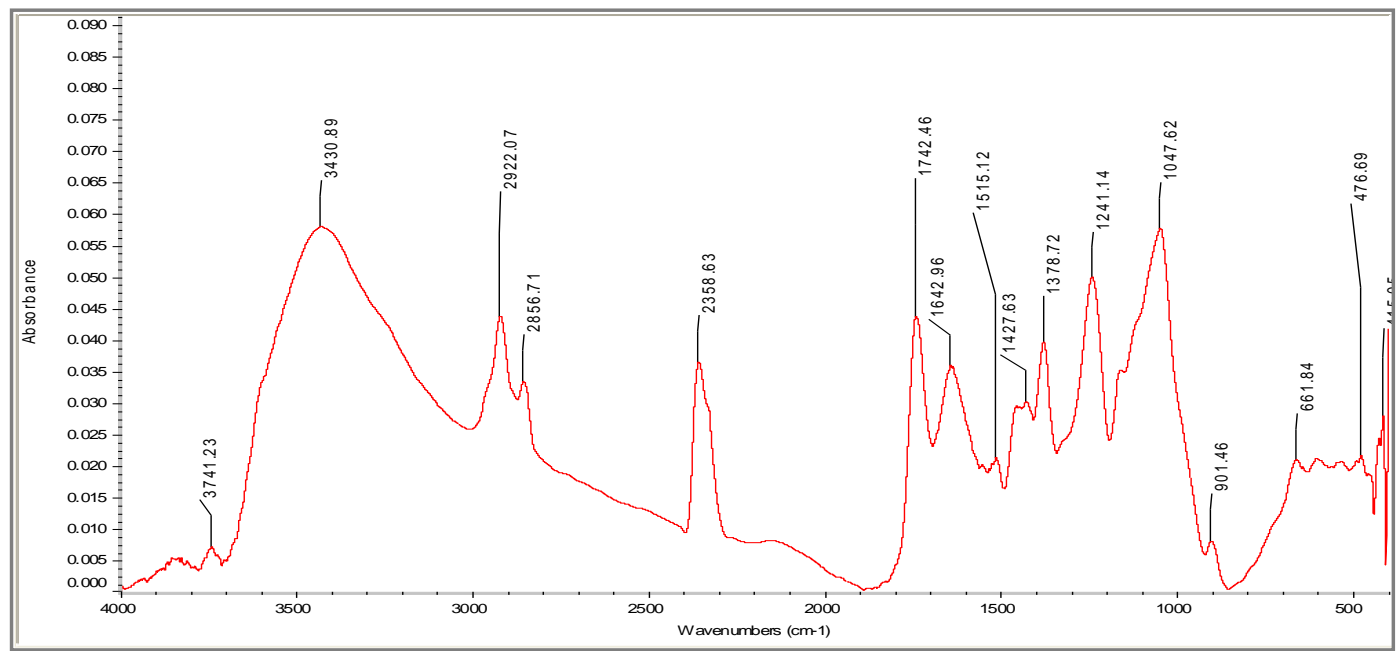

Fig-2: FTIR Spectra of phenol and cyanide loaded Corn Husk leaves 
Further SEM analysis was also done of the adsorbent and immobilized bacteria before and after simultaneous adsorption

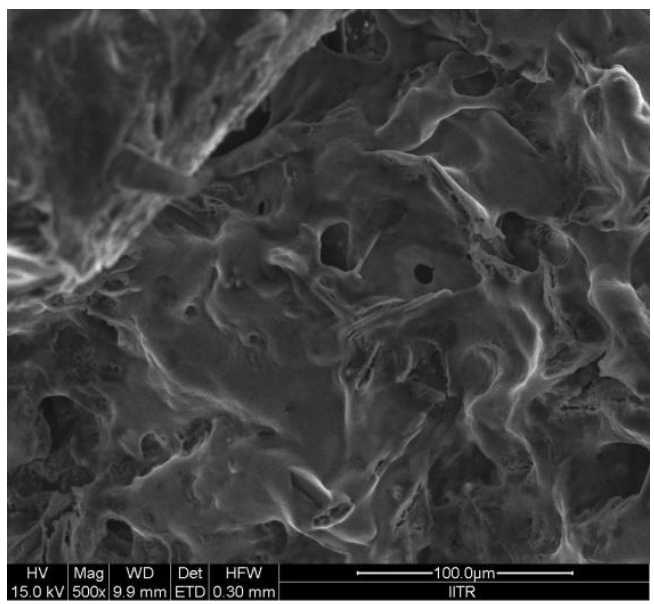

(a) and biodegradation $(\mathrm{SAB})$ are shown below in Fig. 3.

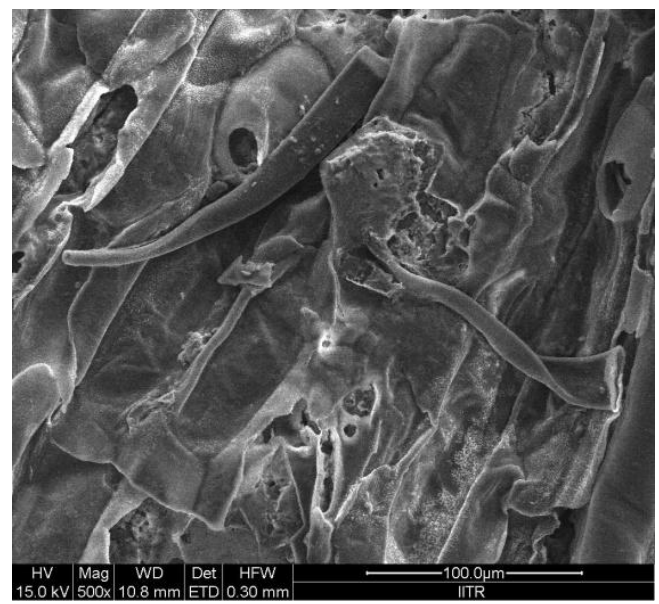

(b)

Fig-3: SEM images of bacteria immobilized on Corn Husk leaves (a) before SAB (b) after SAB

\subsection{Batch Experiments}

Batch experiments were carried out in $250 \mathrm{~mL}$ flat bottom flask. These flasks were kept at an rpm of 125 in an incubator cum orbital shaker (Metrex MO-250, India). The phenol: cyanide ratio is taken as 10:1 as is discharged from coke waste water (Agarwal et. al. 2013). Phenol is highly photo sensitive so the incubator was covered with black cardboard properly throughout the experiment. $400 \mathrm{mg} / \mathrm{L}$ phenol and $40 \mathrm{mg} / \mathrm{L}$ cyanide were taken as initial adsorbate concentrations. Optimum operating parameter study was carried out in the $\mathrm{pH}$ range of 6-10, at a temperature of $300 \mathrm{C}$ and in an adsorbate dose range of 2-10 g/L. All the experiments were carried out for $54 \mathrm{~h}$ and optimum value of operating parameter was obtained at maximum removal keeping in view both the compounds. The initial $\mathrm{pH}$ of the solution was maintained after every $2 \mathrm{~h}$ with $1 \mathrm{~N} \mathrm{NaOH}$ or $\mathrm{HCl}$.For equilibrium studies, the initial concentrations of phenol and cyanide were taken in the range between $100-1000 \mathrm{mg} / \mathrm{L}$ and $10-100 \mathrm{mg} / \mathrm{L}$ respectively. For kinetic study the sample was withdrawn after $6 \mathrm{~h}$ and then was filtered with standard Whatman filter paper Cat No. 1001 125. The filtrate was then analysed for phenol and cyanide using colorimetric method, 4-aminoantipyrene and picric acid method respectively. The amount of phenol and cyanide adsorbed per unit mass of the adsorbent was evaluated by the following mass balance equation:

$$
q=\left(C_{0}-C_{e}\right) V / M
$$

Where $\mathrm{C}_{0}=$ initial concentration $(\mathrm{mg} / \mathrm{L})$ $\mathrm{C}_{\mathrm{e}}=$ Concentration at equilibrium $(\mathrm{mg} / \mathrm{L})$ $\mathrm{V}=$ Volume of the solution $(\mathrm{L})$
$\mathrm{M}=$ Mass of adsorbent $(\mathrm{g})$

\subsection{Equilibrim Isotherms}

Interactive behaviour of adsorbates and adsorbents are described by equilibrium models therefore description of equilibrium models is necessary. Using these models the effect that one component has on the adsorption of the other component and their comparative affinity for binding sites can also be studied [10]. The simple equilibrium models used for typical adsorption processes are Langmuir model, Freundlich model, Toth model, Redlich-Peterson model, Radke-Prausnitz model etc. Keeping in view the present study which is based on the simultaneous removal of pollutants from multicomponent system of phenol and cyanide multicomponent isotherm models are used.In multicomponent systems components interference and compete for active sites which leads to a more complex mathematical formulation of the equilibrium therefore single component models are not capable of fully solving the purpose [10].These complex multi-component systems can be modelled using variants of single isotherm models discussed below from Eq. (4)-(8):

Non-modified competitive Langmuir:

$$
\mathrm{q}_{\mathrm{e}, \mathrm{i}}=\left(\mathrm{Q}_{0, \mathrm{i}} \mathrm{b}_{\mathrm{i}} \mathrm{C}_{\mathrm{e}, \mathrm{i}}\right) /\left(1+\sum_{\mathrm{j}=1}^{\mathrm{N}} \mathrm{b}_{\mathrm{j}} \mathrm{C}_{\mathrm{e}, \mathrm{j}}\right)
$$

Modified competitive Langmuir:

$$
\mathrm{q}_{\mathrm{e}, \mathrm{i}}=\left(\mathrm{Q}_{0, \mathrm{i}} \mathrm{b}_{\mathrm{i}} \mathrm{C}_{\mathrm{e}, \mathrm{i}} / \mathrm{n}_{\mathrm{i}}\right) /\left(1+\sum_{\mathrm{j}=1}^{\mathrm{N}} \mathrm{b}_{\mathrm{j}}\left(\mathrm{C}_{\mathrm{e}, \mathrm{j}} / \mathrm{n}_{\mathrm{j}}\right)\right)
$$


Extended Langmuir:

$$
\mathrm{q}_{\mathrm{e}, \mathrm{i}}=\left(\mathrm{Q}_{0, \mathrm{i}} \mathrm{b}_{\mathrm{i}} \mathrm{C}_{\mathrm{e}, \mathrm{i}}\right) /\left(1+\sum_{\mathrm{j}=1}^{\mathrm{N}} \mathrm{b}_{\mathrm{j}} \mathrm{C}_{\mathrm{e}, \mathrm{j}}\right)
$$

Extended Freundlich:

$$
\begin{aligned}
& \mathrm{q}_{e, i}=\left(\mathrm{K}_{\mathrm{F}, \mathrm{i}} \mathrm{C}_{\mathrm{e}, \mathrm{i}}^{1 /\left(\mathrm{n}_{\mathrm{i}}+\mathrm{x}_{\mathrm{i}}\right)}\right) /\left(\mathrm{C}_{\mathrm{e}, \mathrm{i}}^{\mathrm{x}_{\mathrm{i}}}+\mathrm{y}_{\mathrm{i}} \mathrm{C}_{\mathrm{e}, \mathrm{j}}^{\mathrm{z}_{\mathrm{i}}}\right) \\
& \mathrm{q}_{\mathrm{e}, \mathrm{j}}=\left(\mathrm{K}_{\mathrm{F}, \mathrm{j}} \mathrm{C}_{\mathrm{e}, \mathrm{j}}^{1 /\left(\mathrm{n}_{\mathrm{j}}+\mathrm{x}_{\mathrm{j}}\right)}\right) /\left(\mathrm{C}_{\mathrm{e}, \mathrm{j}}^{\mathrm{x}_{\mathrm{j}}}+\mathrm{y}_{\mathrm{j}} \mathrm{C}_{\mathrm{e}, \mathrm{i}}^{\mathrm{z}_{\mathrm{j}}}\right)
\end{aligned}
$$

\subsection{Kinetic Studies}

The mechanism of adsorption i.e. physisorption or chemisorption along with the time profile and rate constant of the adsorption kinetic are estimated by kinetic studies. Different models used are pseudo first order (physisorption), pseudo second order (chemisorption) Weber and Morris or intraparticle model for mass transfer effects. Equations describing the aforementioned models are given below from Eq. (9)-(11):

Pseudo-first order:

$$
\mathrm{q}_{\mathrm{t}}=\mathrm{q}_{\mathrm{e}}\left(1-\exp \left(-\mathrm{k}_{1} \mathrm{t}\right)\right)
$$

Pseudo-second order:

$$
\mathrm{q}_{\mathrm{t}}=\mathrm{k}_{2} \mathrm{q}_{\mathrm{e}}^{2} \mathrm{t} /\left(1+\mathrm{q}_{\mathrm{e}} \mathrm{k}_{2} \mathrm{t}\right)
$$

Intraparticle:

$$
\mathrm{q}_{\mathrm{t}}=\mathrm{k}_{\mathrm{id}} \mathrm{t}^{1 / 2}
$$

\subsection{Model Validation}

The error function, namely, Average Relative Error (ARE) was used for validation of kinetic models as well as for equilibrium isotherms. For ARE evaluation, equation given is:

$$
\operatorname{ARE} \%=100 / \mathrm{N} \times \sqrt[2]{\sum\left(\frac{\mathrm{q}_{\mathrm{e}, \mathrm{i}}^{\mathrm{exp}}-\mathrm{q}_{\mathrm{e}, \mathrm{i}}^{\text {cal }}}{\mathrm{q}_{\mathrm{e}, \mathrm{i}}^{\mathrm{exp}}}\right)^{2}}
$$

\section{RESULTS AND DISCUSSION}

\subsection{Effect of $\mathrm{pH}$}

The effect of $\mathrm{pH}$ was studied in the range of 6-10. The microbe used in the process i.e. bacteria of Serratia Sp. ceased to grow in extreme acidic and extreme alkaline conditions. Fig. 4 shows the change in percentage removal of phenol and cyanide with $\mathrm{p}^{\mathrm{H}}$. The percentage removal of phenol shows a decrease after the $\mathrm{pH} 7$ and shows a maximum removal of 76 $\%$ at a $\mathrm{p}^{\mathrm{H}}$ between 6 and 7 . This shows that phenol adsorption takes place mainly in its undissociated form as phenol has a pKa of 9.96 under which it remains in undissociated form. In case of cyanide the removal percentage shows a maximum of $96 \%$ at pH 7 and then decreases in alkaline conditions. Since the $\mathrm{pH}$ is not reduced below 6 , the pressure is maintained and there is no evolution of HCN [11]. Since the pKaof cyanide is 9.39 therefore cyanide also shows the behaviour of getting adsorbed in its undissociated form.

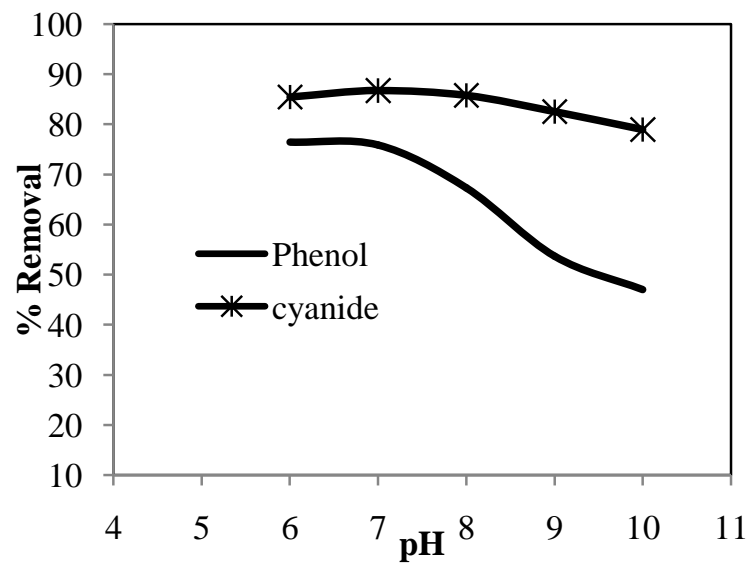

Fig-4: Effect of $\mathrm{pH}$ on removal of phenol and cyanide by SAB

\subsection{Effect of Adsorbent Dose}

Adsorbent dose effect was studied on the co-adsorptive removal of phenol and cyanide between the doseof 2-10 g/L. From the Fig.5shows that the percentage removal for both phenol and cyanide increases with adsorbent dose till $6 \mathrm{~g} / \mathrm{L}$ and then it becomes constant. The initial increase in percentage removal with increase in adsorbent dose is due to the increase in active sites. However above certain dose removal percentage assumes an asymptotic value. With increase in adsorbent dose there can be an overlapping of active sites which decreases the surface area on the adsorbent. Optimum removal of $76 \%$ phenol and $85 \%$ cyanide occurs at $6 \mathrm{~g} / \mathrm{L}$ therefore it is taken as optimum adsorbent dose.

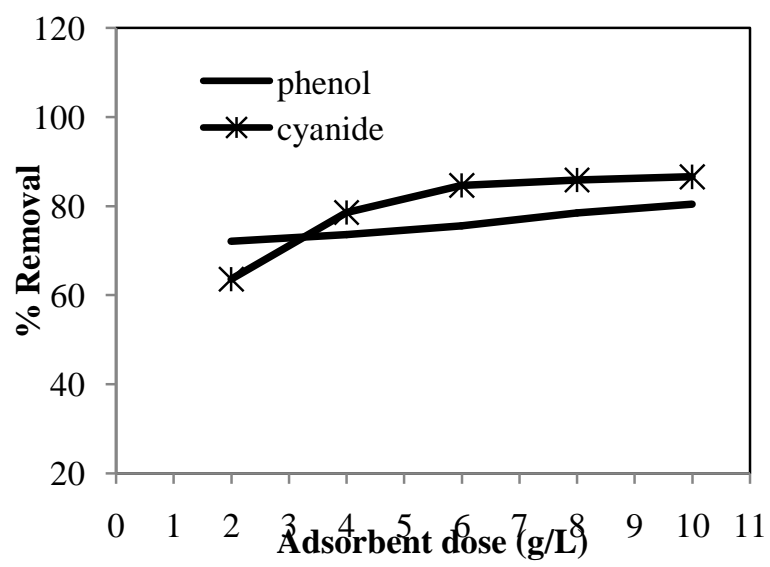

Fig-5: Effect of adsorbent dose on the SAB process of phenol and cyanide 


\subsection{Effect of Initial Concentration}

Driving force to overcome mass transfer limitations between sorbate and sorbent is provided by initial adsorbate concentration. In the case of phenol, fig 6(a) a maximum percentage removal of about $97 \%$ takes place at a concentration of $100 \mathrm{mg} / \mathrm{l}$ which further decreases by increasing the initial concentration from 200-1000 mg/L.
Similarly fig 6 (b) shows cyanide removal around $90 \%$ at a concentration of $10 \mathrm{mg} / \mathrm{l}$ which decreases further with increasing concentration till $100 \mathrm{mg} / \mathrm{l}$. At low concentrations the active sites are easily occupied by sorbent molecules which show a high percentage removal while at a high concentration saturation of binding capacity of adsorbents of adsorbent can take place which decreases removal [12].

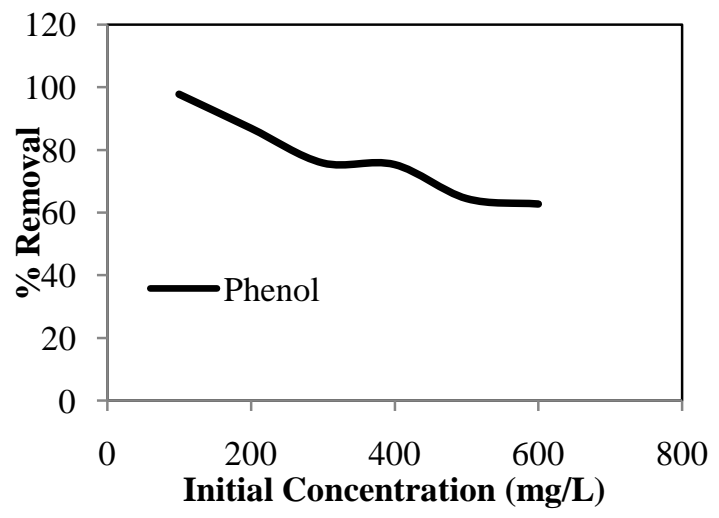

(a)

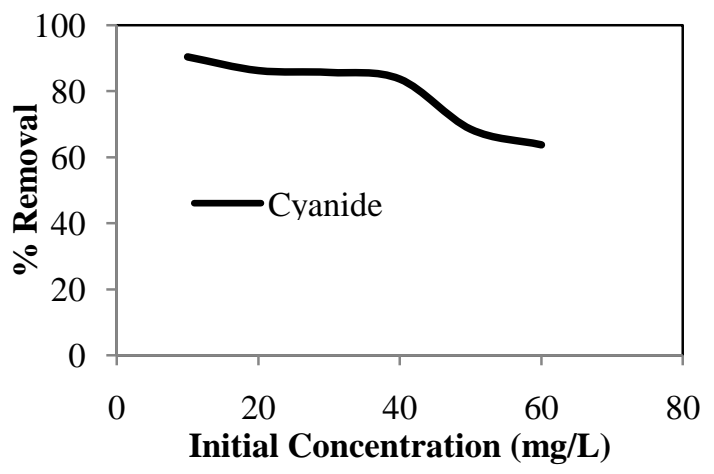

(b)

Fig-6: Effect of initial concentration of (a) phenol and (b) cyanide on the SAB process

\subsection{Effect of Contact Time}

Contact time study is essential for the adsorption study as it is an important parameter for determination of equilibrium time of adsorption process. From fig. 7 it is clearly seen thatfor phenol an increase in removal is witnessed till $30 \mathrm{~h}$ where it shows the maximum removal of $73.36 \%$ and after that it becomes constant. Similarly for cyanide the study revealed that cyanide showed a trend of increasing removal with time and reached a maximum till50 h. For both phenol and cyanide the initial removal takes place by simple adsorption and then the further increase in removal is adhered to the fact the occupied sites are freed due to biodegradation [7].

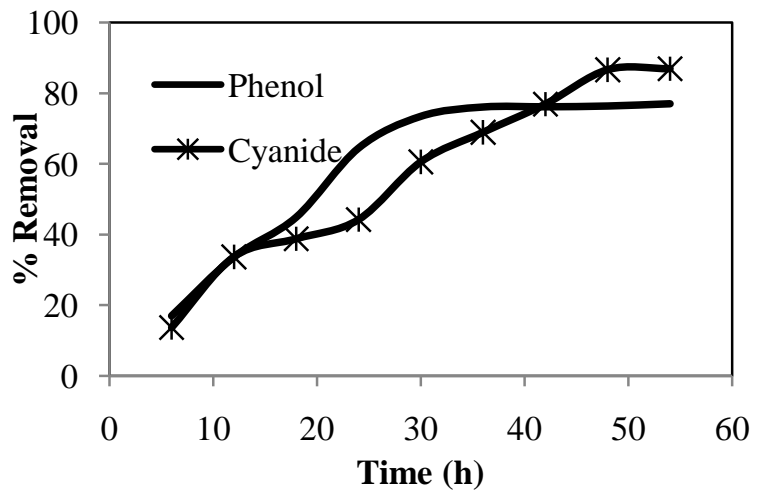

Fig-7: Effect of Contact time on the removal of phenol and cyanide by SAB process

\subsection{Equilibrium Modelling:}

The simultaneous adsorption and biodegradation equilibrium data for phenol and cyanide on corn husk leaves was analysed using Solver function of Microsoft excel 2010. The data for multicomponent adsorption of phenol and cyanide onto corn husk leaves were fitted to different multicomponent isotherm models i.e. Non-modified Langmuir, Modified Langmuir, Extended Langmuir and Extended Freundlich. These multicomponent models use the constants from single component models. The predictability of these models were analysed using Average Relative Error (ARE). The data of different isotherm models is shown in table 1. From table 1 it can be seen that Non-modified Langmuir isotherm shows best the simultaneous adsorption and biodegradation of phenol with an ARE value of 9.597. Whereas Modified Langmuir Isotherm shows best the simultaneous adsorption and biodegradation of cyanide with an ARE value of 20.79 . 
Table-1: Study of multi-component isotherms for the SAB process of phenol and cyanide

\begin{tabular}{|l|l|l|}
\hline \multirow{2}{*}{ Parameters and ARE } & Present Study \\
\cline { 2 - 3 } & Non-modified Langmuir Isotherm \\
\cline { 2 - 3 } & Phenol (i=1) & Cyanide (i=2) \\
\hline $\mathrm{Q}_{0, \mathrm{i}}$ & 45.172 & 7.393 \\
\hline $\mathrm{b}_{\mathrm{i}}$ & 0.216 & 0.255 \\
\hline $\mathrm{ARE}$ & 9.597 & 32.353 \\
\hline & Modified Langmuir Isotherm \\
\hline $\mathrm{Q}_{0, \mathrm{i}}$ & 45.172 & 7.393 \\
\hline $\mathrm{b}_{\mathrm{i}}$ & 0.216 & 0.255 \\
\hline $\mathrm{n}_{\mathrm{i}}$ & 2.595 & 0.522 \\
\hline $\mathrm{ARE}$ & 19.028 & 20.79 \\
\hline & Extended Langmuir Isotherm & \multicolumn{1}{|l}{} \\
\hline $\mathrm{Q}_{0, \mathrm{i}}$ & 99.646 & 2.624 \\
\hline $\mathrm{b}_{\mathrm{i}}$ & 2.186 & 0.255 \\
\hline $\mathrm{ARE}$ & 11.317 & 27.197 \\
\hline & Extended Freundlich Isotherm & \multicolumn{2}{|l}{} \\
\hline $\mathrm{K}_{\mathrm{F}, \mathrm{i}}$ & 12.213 & 1.709 \\
\hline $\mathrm{n}_{\mathrm{i}}$ & 3.477 & 2.178 \\
\hline $\mathrm{x}_{\mathrm{i}}$ & -2.564 & -3.545 \\
\hline $\mathrm{y}_{\mathrm{i}}$ & 1.748 & 0.391 \\
\hline $\mathrm{z}_{\mathrm{i}}$ & 1.231 & 0.958 \\
\hline $\mathrm{ARE}$ & 15.357 & 37.716 \\
\hline
\end{tabular}

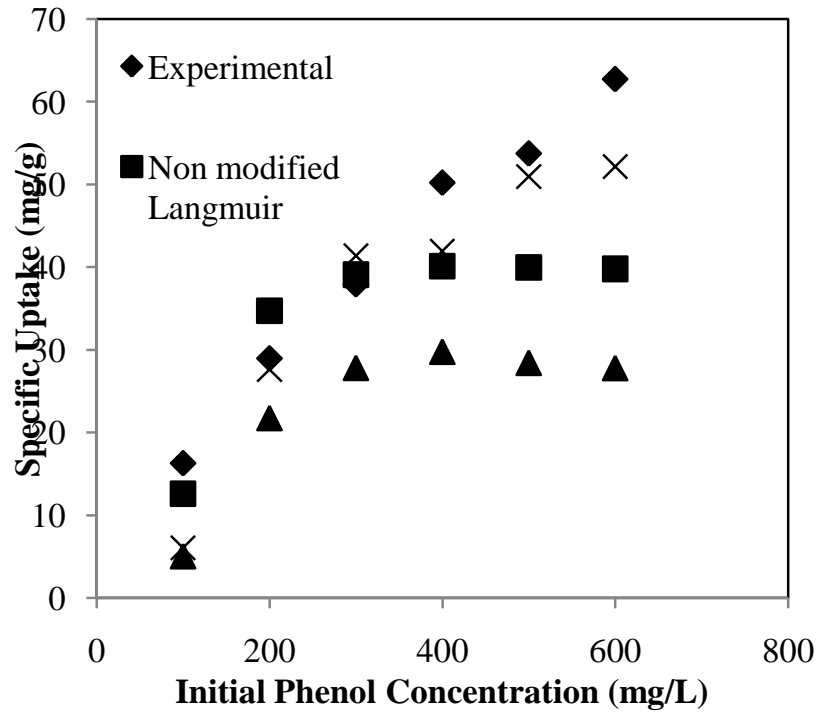

Fig-8: Equilibrium isotherms for phenol at $300 \mathrm{C}$ at $400 \mathrm{mg} / \mathrm{L}$ concentration

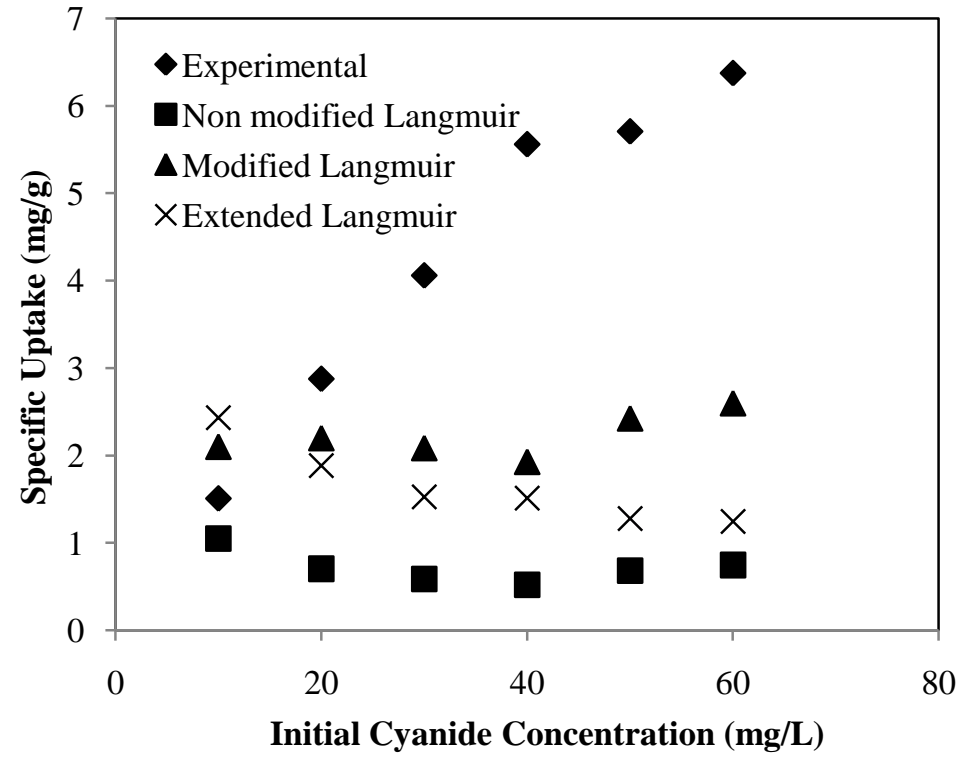

Fig-9: Equilibrium isotherms for cyanide at $300 \mathrm{C}$ at $40 \mathrm{mg} / \mathrm{L}$ concentration

From fig 8.and fig 9. It can again be seen that the closest to phenol experimental data is given by non-modified Langmuir adsorption isotherm and for cyanide the closest fit is given by modified adsorption isotherm. 


\subsection{Kinetic Studies}

Estimation of adsorption mechanism i.e.physisorption (pseudo-first order) or chemisorption (pseudo- second order) can be determined by kinetic modelling. From table 2 given below the inferences drawn are as follows: kinetic data prediction of phenol is better shown by pseudo-first order model as it has a lower ARE but since there is not much difference in the ARE for both the models it can be said that phenol adsorption takes place both by physisorptionand chemisorption whereas for cyanide kinetic data can be better predicted by pseudo second order kinetics attributing to the fact of lower ARE but due to slight difference in ARE values for pseudo first order and second order kinetics cyanide adsorption kinetics can also be predicted by both first and second order kinetics. Hence for both phenol and cyanide adsorption takes place both by physisorption and chemisorption. Diffusion nature is determined by graph of $\mathrm{q}_{\mathrm{t}} \mathrm{vs}$ $\mathrm{t}^{0.5}$. The graph of $\mathrm{q}_{\mathrm{t}} \mathrm{vs} \mathrm{t}^{0.5}$ was plotted for both phenol and cyanide. According to [6] the plot should be linear for the involvement of intraparticle diffusion. Since the obtained plot fig. is non-linear and it does not pass through origin, intraparticle diffusion is not the rate controlling step and other kinetic models control the rate of adsorption [3,8].For phenol $\left(\mathrm{R}_{1}{ }^{2}>\mathrm{R}_{2}{ }^{2}\right)$ which indicates surface diffusion to be dominating whereas for cyanide $\left(\mathrm{R}_{2}{ }^{2}>\mathrm{R}_{1}{ }^{1}\right)$ which shows that intraparticle diffusion as the dominating step [2].

Table-2: Kinetic data estimation for $\mathrm{SAB}$ process of phenol and cyanide

\begin{tabular}{|l|l|l|}
\hline \multirow{2}{*}{ Parameters and ARE } & Present Study \\
\cline { 2 - 3 } & Pseudo First Order Kinetics \\
\cline { 2 - 3 } & Phenol & Cyanide \\
\hline $\mathrm{q}_{\mathrm{e}, \mathrm{cal}}$ & 66.445 & 10.278 \\
\hline $\mathrm{k}_{1}$ & 0.034 & 0.016 \\
\hline $\mathrm{ARE}$ & 4.043 & 4.003 \\
\hline & Pseudo Second Order Kinetics \\
\hline $\mathrm{q}_{\mathrm{e}, \mathrm{cal}}$ & 104.548 & 17.502 \\
\hline $\mathrm{k}_{2}$ & 0.000215 & 0.000548 \\
\hline ARE & 4.557 & 3.992 \\
\hline & Intraparticle & \multicolumn{2}{|l}{} \\
\hline $\mathrm{k}_{\mathrm{d} 1}$ & 11.862 & 1.013 \\
\hline $\mathrm{R}_{1}{ }^{2}$ & 0.9805 & 0.9703 \\
\hline $\mathrm{k}_{\mathrm{d} 2}$ & 0.657 & 0.0428 \\
\hline $\mathrm{R}_{2}{ }^{2}$ & 0.9182 & 1 \\
\hline
\end{tabular}

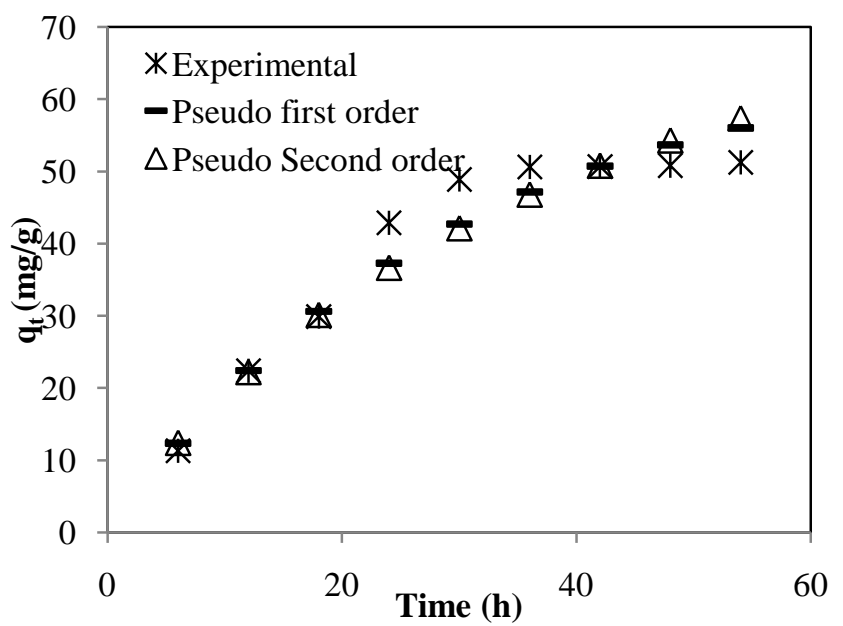

Fig-10: Comparative plots for experimental and calculated values of $\mathrm{q}_{\mathrm{t}}$ by pseudo first order and pseudo second order kinetics for phenol at $30^{\circ} \mathrm{C}$ and $400 \mathrm{mg} / \mathrm{L}$ concentration

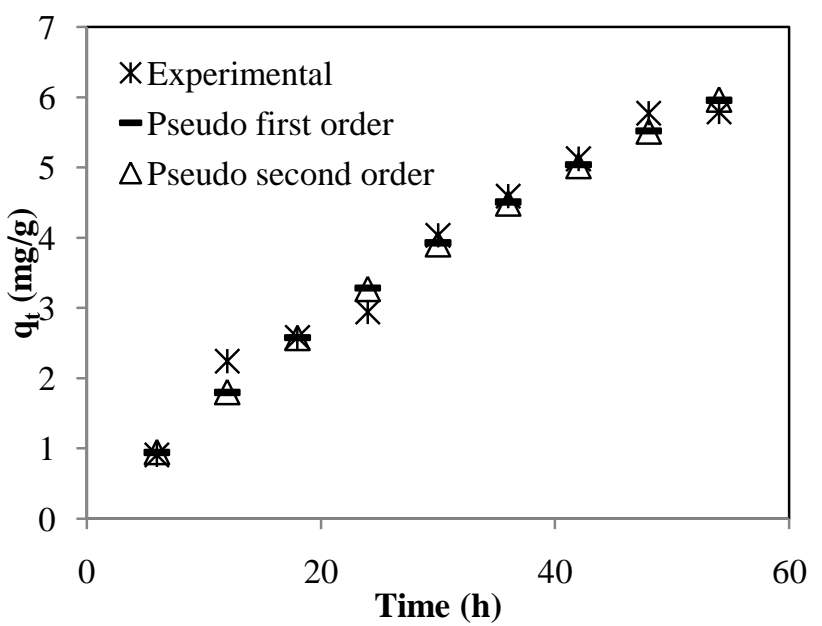

Fig-11:Comparativeplots for experimental and calculated values of qt by pseudo first order and pseudo second order kinetics for cyanide at $300 \mathrm{C}$ and $40 \mathrm{mg} / \mathrm{L}$ concentration 


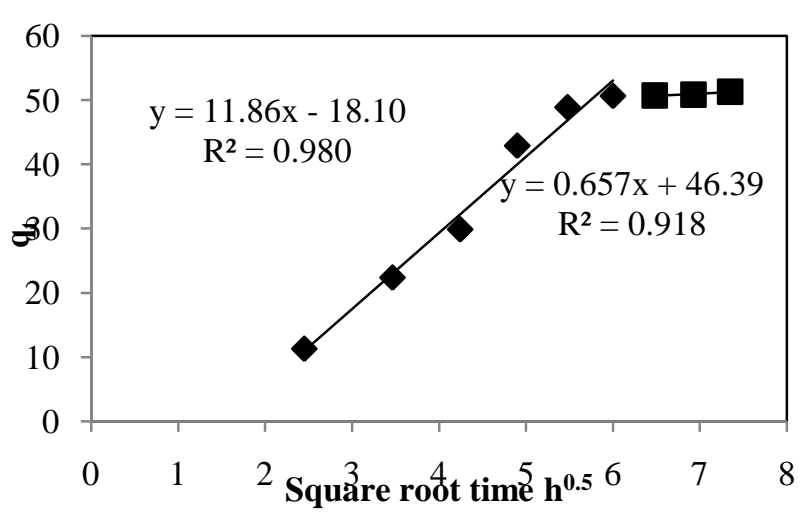

Fig-12: Intraparticle plots for phenol

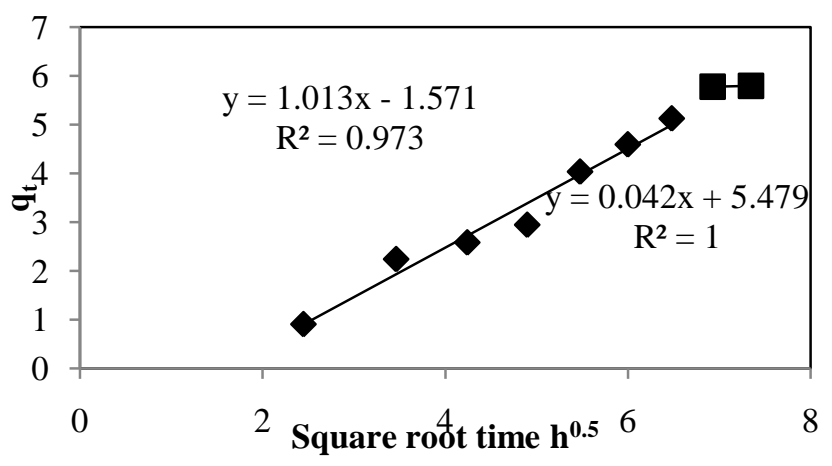

Fig-13: Intraparticle plots for cyanide

\section{CONCLUSIONS}

Present study is based on removal of phenol and cyanide by simultaneous adsorption and biodegradation. The biosorbent used in this process is Corn Husk leaves and the microbe used is the bacteria of Serratia Sp. The initial concentration for phenol and cyanide was taken as $400 \mathrm{mg} / \mathrm{L}$ and $40 \mathrm{mg} / \mathrm{L}$ respectively and the $\mathrm{SAB}$ experiments were performed for 60 $\mathrm{h}$ at $30^{\circ} \mathrm{C}$. The optimum $\mathrm{pH}$ was between 6-7 and the optimum adsorbent dose was estimated as $6 \mathrm{~g} / \mathrm{L}$. The removal of phenol and cyanide were $75 \%$ and $83 \%$ respectively. Equilibrium isotherms plotted showed that $\mathrm{SAB}$ of phenol was best estimated by non- modified Langmuir isotherm and SAB of cyanide was best estimated by modified Langmuir isotherm. Kinetic studies revealed that SAB process of both phenol and cyanide takes place by both physisorption and chemisorption and that for Phenol surface diffusion is dominating and for cyanide intraparticle is dominant but since the intraparticle plots do not pass through origin which shows that intraparticle diffusion is not the rate controlling step.

\section{ACKNOWLEDGEMENTS}

The authors are thankful to Ministry of Human Resource Development, Government of India and Institute's Instrumentation Center, IIT Roorkee for extending their financial and technical support for present research work.

\section{REFERENCES}

[1] Z. Aksu, F. Gonen, Biosorption of phenol by immobilized activated sludge in a continuous packed bed: prediction of breakthrough curves, Process Biochemistry 39 (2004) 599-613.

[2] B. Agarwal ,C.B. Majumder, P.K. Thakur, Simultaneous co-adsorptive removal of phenol and cyanide from binary solution using granular activated carbon, Chem. Eng. J. 228 (2013) 655-664.

[3] G. Moussavi, R. Khosravi, Removal of cyanide from wastewater by adsorption onto pistachio hull wastes: Parametric experiments, kinetics and equilibrium analysis, J. of Hazard. Mater. 183 (2010) 724-730.

[4] CERCLA, The Priority List of Hazardous Substances, Substance Priority List (SPL), from the Comprehensive Environmental Response, Compensation, and Liability Act (CERCLA) section 104 (i), as amended by the Superfund Amendments and Reauthorization Act (SARA).

[5] R. R. Dash, A. Gaur, C.Balomajumder, Cyanide in industrial wastewaters and its removal: A review on biotreatment, J. Hazard. Mater. 163 (2009) 1-11.

[6] M. Kilic, E. Apaydin-Varol, A. E. Putun, Adsorptive removal of phenol from aqueous solutions on activated carbon prepared from tobacco residues: Equilibrium, kinetics and thermodynamics, J. Hazard. Mater. 189 (2011) 397-403.

[7] B. Agarwal ,C. Balomajumdar, Simultaneous Adsorption and Biodegradation ofPhenol and Cyanide in Multicomponent System, Inter. J. Environ. Eng. Manage.ISSN 2231-1319, Volume 4, Number 3 (2013), pp. 233-238

[8] R.R. Dash, C. Balomajumder, A. Kumar, Treatment of cyanide bearing water/wastewater by plain and biological activated carbon, Ind. Eng. Chem. Res. 48(7) (2009) 3619-3627.

[9] G. Moussavi, S. Talebi, Comparing the efficacy of a novel waste-based adsorbentwith PAC for the simultaneous removal of chromium (VI) and cyanide from electroplating wastewater, Chem.Eng.Res.Des.90 (2012) 960-966.

[10] B.Agarwal, P.Sengupta, C.Balomajumder, Equilibrium, Kinetic and Thermodynamic Studiesof Simultaneous Co-Adsorptive Removal of Phenoland Cyanide Using Chitosan, Inter. J. Chem., Mater. Sci. Eng. Vol:7 No:11, 2013.

[11] M.D. Adams, Removal of cyanide from solution using activated carbon, Minerals Eng.7 (1994) 1165-1177.

[12] R.K. Vedula , C. Balomajumder, Simultaneous Adsorptive Removal of Cyanide and Phenol fromIndustrial Wastewater: Optimization of Process Parameters, Res .J. Chem. Sci. Vol. 1(4) 30-39 (2011). 